Vietnam Journal of Earth Sciences 36 (2014) 451-461

Vietnam Academy of Science and Technology
(VAST)
Wietnam Journal of Earth Sciences
Website: http://www.vjs.ac.vn/index.php/jse

\title{
Probabilistic seismic hazard assessment for the South Central Vietnam
}

\author{
Nguyen Hong Phuong ${ }^{*}$, Pham The Truyen \\ Institute of Geophysics, Vietnam Academy of Science and Technology
}

Accepted 27 December 2014

\section{ABSTRACT}

In this paper, the probabilistic seismic hazard maps for the South Central Vietnam are presented. An earthquakes catalog updated until 2014 and most recent seismotectonic and geodynamic information were used for delineation of 14seismic source zones in the study area. The Toro et al. (1997) attenuation equation was used for the PSHA. The hazard maps show distribution of the mean peak ground acceleration (PGA) with a $10 \%, 5 \%, 2 \%$ and $0.5 \%$ probability of exceedance in 50 years.

The highest values of PGA are observed in the continental shelf of the South Central Vietnam, in the $109^{\circ}$ meridian source zone, where the maximum PGA values are $0.12,0.15,0.2$ and $0.28 \mathrm{~g}$ corresponding to the return times of about 500, 1000, 2500 and 10000 years, respectively. In addition, two seismic source zones that can produce strong ground shaking off-shore South Central coast are Cuu Long - Con Son and Thuan Hai - Minh Hai. For the time period of about 1000 years, the highest shaking intensity within these source zones reaches the value of VIII (I=VIII by MSK-64 scale).In the territory of South Central Vietnam, the strongest shaking are observed in the Quang Nam and Quang Ngai provinces, in the Hung Nhuong - Ta Vi seismic source zone. For the return times of about 500,1000, 2500 and 10000 years, the highest PGA values in this zone are $0.1,0.12,0.14$ và $0.17 \mathrm{~g}$, respectively. Strong ground shakings are also observed in some other seismic source zones as Tuy Hoa - Cu Chi, Hau river and Nha Trang - Tanh Linh.

ThePGA maps present both short-term and long-term forecasts of seismic hazard in the South Central Vietnam and can be used as a reference for antiseismic design and many engineering applications.

(C) 2014 Vietnam Academy of Science and Technology

\section{Introduction}

The South Central Vietnam region consists of the independent municipality of Da Nang, seven coastal provinces from Quang Nam in the north to Ninh Thuan in the south, and four provinces of the Central highland, namely Kon Tum, Gia Lai, Dak Lak and Lam Dong. The South Central region, particularly the South Central Coast plays a specific role in economy and industry development of Vietnam. Located in the junction of all road, rail, air and sea transportation, near the Ho Chi

*Corresponding author, Email: phuong.dongdat@gmail.com
Minh city and the triangle economic zone of Eastern South Vietnam, being a gateway to the Trans - Asian and international maritime transportation, many international airports and deep sea ports are distributed along the South Central Coast. Many coastal cities are very wellknown for tourists as Da Nang - Hoi An, Quy Nhon - Nha Trang - Cam Ranh - Ninh Chu - Mui $\mathrm{Ne}$ are all located in the South Central Vietnam coast. The country's first two nuclear power plants are under construction in Ninh Thuan province.

The fast growing of economy in the South Central Vietnam is, however, coupled with the 
Nguyen Hong Phuong et al./Vietnam Journal of Earth Sciences 36 (2014)

challenge of facing the high risk from natural disaster. Not only suffering from the floods and storms every year, the region is also threatened by earthquakes and tsunamis. Recent research reveals a high seismicity level in the off-shore areas as well as high tsunami hazard from the East Vietnam Sea that can affect the South Central Vietnam (N. H. Phuong, 1999, 2010; N. H. Phuong et al., 2012, 2014). Therefore, a seismic hazard assessment is necessary for the Southern Central Vietnam in the sense that it may provide the important and quantitative information for natural disaster emergency response and risk management in the region.

This study aims at a probabilistic seismic hazard analysis for the South Central Vietnam region. Based on a catalog of earthquakes updated until 2014 and most recent seismotectonic and geodynamic information, a map of 15 seismic source zones were determined, and probabilistic procedure was used to calculate the shaking for the whole study area. The results are presented in terms of a set of ground shaking maps, predicting values of peak ground acceleration for the study area in different time periods.

\section{Seismicity of the southcentral Vietnam}

Far from giant tectonic margins, not experienced strong tectonic changes since 15 millions years, the South Central Vietnam is considered to be a passive marginal zone, belonging to a stable part of continental crust. Many authors have pointed out that this area is located in a stable tectonic plate named Sunda, which is characterized by low level of seismicity and deformation (Petersen et al, 2004). As a master of fact, not many earthquakes, and no earthquake with magnitude exceeded 6.1 have been recorded in the South Central and South Vietnam up to now. Only after the occurrence of a swarm earthquakes offshore the Southeastern coast of Vietnam in 2005 that shook many coastal cities, the problem of earthquake hazard in South Central Vietnam began to cause more attention in the country.

In order to assess the seismicity of the South Central Vietnam, earthquakes data were collected from many sources, including historical, macroseismical and instrumental as well. The description of most typical earthquakes occured in South Central Vietnam are given bellow.
(1) The Phan Thiet earthquake of 9/1877, occurred in Binh Thuan province, as described in the historical book named "Đại Nam thực lục": "Earthquakes, since then to December occurred 3 times, the first shaking caused high waves from river and shook the masonry houses, the rest two shakings were smaller".

(2) The Phan Thiet earthquake of 7/1882, occurred in Binh Thuan province, with roars heard from the sea like canon sounds for all day (V. M. Giang, 2000). N. K. Mao (1974) wrote that in 1882, earthquake occurred in a coastal zone, causing high waves from the sea, followed by many blast-like sounds during a day. There was no information on volcanic activities related to this earthquake. However, it is written in a historical book "Đại Nam nhất thống chí" (Volume 12) as follows: "in Binh Thuan, there is a swarm of volcanoes in the northern part of Tuy Phong ward, next to Hoa Da ward in the north. The swarm consists of about ten volcanoes standing next to each other. In summer, during a hot time, the fire columns are erupted from volcanoes continuously, non stop, look like a burning citadel (collected and quoted by N.K. Mao, 1974).

(3) The Hon Tro earthquakes of $15 / 02 / 1923$ and 2/05/1923: These earthquakes are related to eruption of the Hon Tro volcano $\left(10.10^{0} \mathrm{~N}\right.$, $109.00^{\circ} \mathrm{E}$ ). According to Minh Đô sử (Minh's Dynasty Historical Book), Vol. 23, the volcanos eruptions and related shaking are described as: "Earthquakes were followed by roars sounded like thunders, the sea waters shot highly in the air during many days in the Phu Qui island, sometimes 4-5 times, sometimes 20-30 times a day". P. V. Thuc (2008) described activities of volcanos and earthquakes in the coastal zones of Central Vietnam as follows: "Before eruptions, starting from 15/02/1923 many places of Phan Thiet, $\mathrm{Cu}$ lao Hon island were strongly shook, houses tilted, people could not stand but sea level did not disturb. The shakings lasted a week, and then when the Japanese ship Vacasamuru passed by, they observed a black column of smoke and a dense column of gaz of more than $2000 \mathrm{~m}$ height coupled with blasting sounds". Based on hydrothermal and $\mathrm{C}^{14}$ data analysis, the authors conclude that the magma of the Hon Tro volcano was erupted from a depth of $60-70 \mathrm{~km}$. 
Vietnam Journal of Earth Sciences 36 (2014) 451-461

(4) The Song Cau earthquakes (Phu Yenprovince) of 1970 and 1972. In the area near epicentral zone the houses were stronly shook, all the people can feel the shakings and many of them ran out of their houses in panic (N. D. Xuyen et al., 1981). Only one common izoseismal map was compiled for both earthquakes due to the fact that although the two earthquakes were clearly distinguished by time, the shaking information provided by local people did not allow to distinguish these two events. Instrumentally these earthquakes were recorded by Bac Giang seismic station and appeared in the earthquake list of ISC. While ISC data gave no record on magnitude, Vietnamese seismoligists at Institute of Geophysics have estimated magnitudes of these earthquakes as 5.3 and 5.1 based on the shaking intensity at epicetral zone and data of Bac Giang seismic station.

(5) A swarm of earthques offshore Vung Tau Phan Thiet in 2005: occuring offshore Vung Tau Phan Thiet, this swarm of earthquakes was felt along the coast of Southeastern Vietnam in Phan Thiet, Vung Tau, Ho Chi Minh city and other provinces. It started with a M4.5 event on $05 / 08 / 2005$. Shakings from this earthquake weave the drilling platform $\mathrm{N}^{\circ} 2$ in Bach Ho offshore well. In Vung Tau city, tremors was felt by many people, long enough to rattle disshes and furnitures. In Dong Nai, people ran out of their houses in panic. In Ho Chi Minh city, crowds of people gathered on the street for a long time, not daring to return home.On 16/1/2005, another earthquake struck offshore Vung Tau - Phan Thiet that shook the high rise buildings in the Ho Chi minh city. However, the strongest event of the swarm occured on 7 and $8 / 11 / 2005$. The first shock occured at 0 hour 15 minutes $50.80 \mathrm{sec}$. (local time) at $10.08^{\circ} \mathrm{N}, 108.26^{\circ} \mathrm{E}$, depth $12 \mathrm{~km}$ and $\mathrm{M}_{\mathrm{w}}=5.2$. The second shock occured at 14 hours $54 \mathrm{~min} .39 \mathrm{sec}$. (local time) at $10.12^{\circ} \mathrm{N}$, $108.26^{\circ} \mathrm{E}$, depth $12 \mathrm{~km}$ and $\mathrm{M}_{\mathrm{w}}=5.3$. These two event occured almost in one place, with almost the same intensity. Their shakings were felt in a large area, from Vung Tau - Phan Thiet through Ho Chi Minh city and up to Nha Trang, Phu Yen, Da Lat, Di Linh, Bao Loc and Buon Me Thuot, Can Tho and Tay Ninh. The isoseismal map of this earthquake was compiled at the Institute of Geophysics and is shown in Fig. 1 (L. T. Son et al., 2006).

The data on source mechanism of these earthquakes was determined by Hardvard
Seismology as shown in Table 1 (http: Harvard Seismology Centroid Moment Tensor Catalog.htm). The focal mechanism of these earthquakes are quite similar, suggesting that the source fault plane has a NEN direction, with leftlateral - normal movement and dip angle of about $79^{\circ}-82^{\circ}$ plunging toward the ESE direction. The compressional axis is of meridional direction, and tensional axis is of latitudinal direction. According to observation data of Nha Trang seismic station, the swarm was preceeded by small earthquake of M>3.0 since begining of 2005 and lasting until 2006 with decreasing frequency and mafnitude. In $7 / 2006$ an earthqukae of M4.5 still observed in this region. It should be emphasised that the M5.3 earthquake of $8 / 11 / 2005$ is the largest one among the other in the swarm and at the same time it is the biggest event recorded in South Central Vietnam as well as in the South Vietnam over last century. Fig. 2 also shows distribution of the earthquake swarm within the area of $9.90^{\circ} \mathrm{N}$ $10.38^{\circ} \mathrm{N}$ and $108.20^{\circ} \mathrm{E}-108.65^{\circ} \mathrm{E}$.

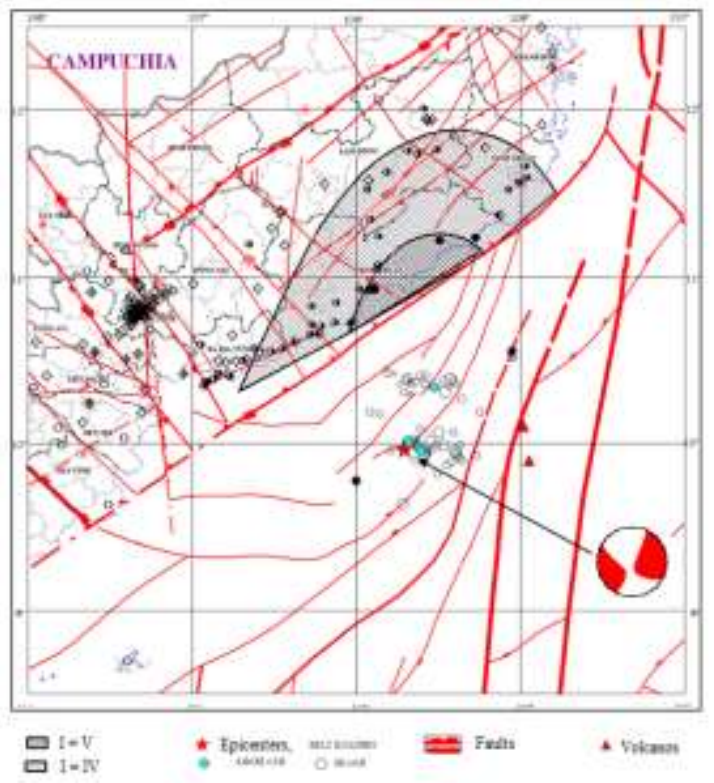

Fig. 1. Isoseismal map of the Phan Thiet - Vung Tau M5.3 earthquake of 8/11/2005. Distribution of the Phan Thiet - Vung Tau earthquake swarm of 2005 within the area of $9.90^{\circ} \mathrm{N}$ $10.38^{\circ} \mathrm{N}$ and $108.20^{\circ} \mathrm{E}-108.65^{\circ} \mathrm{E}$, at a distance of $40-80 \mathrm{~km}$ westward to the Hon Tro volcanic earthquke (1923) also shown (L. T. Son et al., 2006)

For seismic hazard assessment of the South Central Vietnam, a catalog of 95 eventswas compiled, which consists of both historical and 
Nguyen Hong Phuong et al./Vietnam Journal of Earth Sciences 36 (2014)

instrumental dataand covers a region between $8.3^{\circ}-$

Fig. 2). The instrumental data of the catalog were $16.5^{\circ} \mathrm{N}$ lattitudes and $105^{\circ}-112^{\circ} \mathrm{E}$ longitudes(see

Table 1. Focal mechanism of the 2005 offshore Vung Tau earthquakes

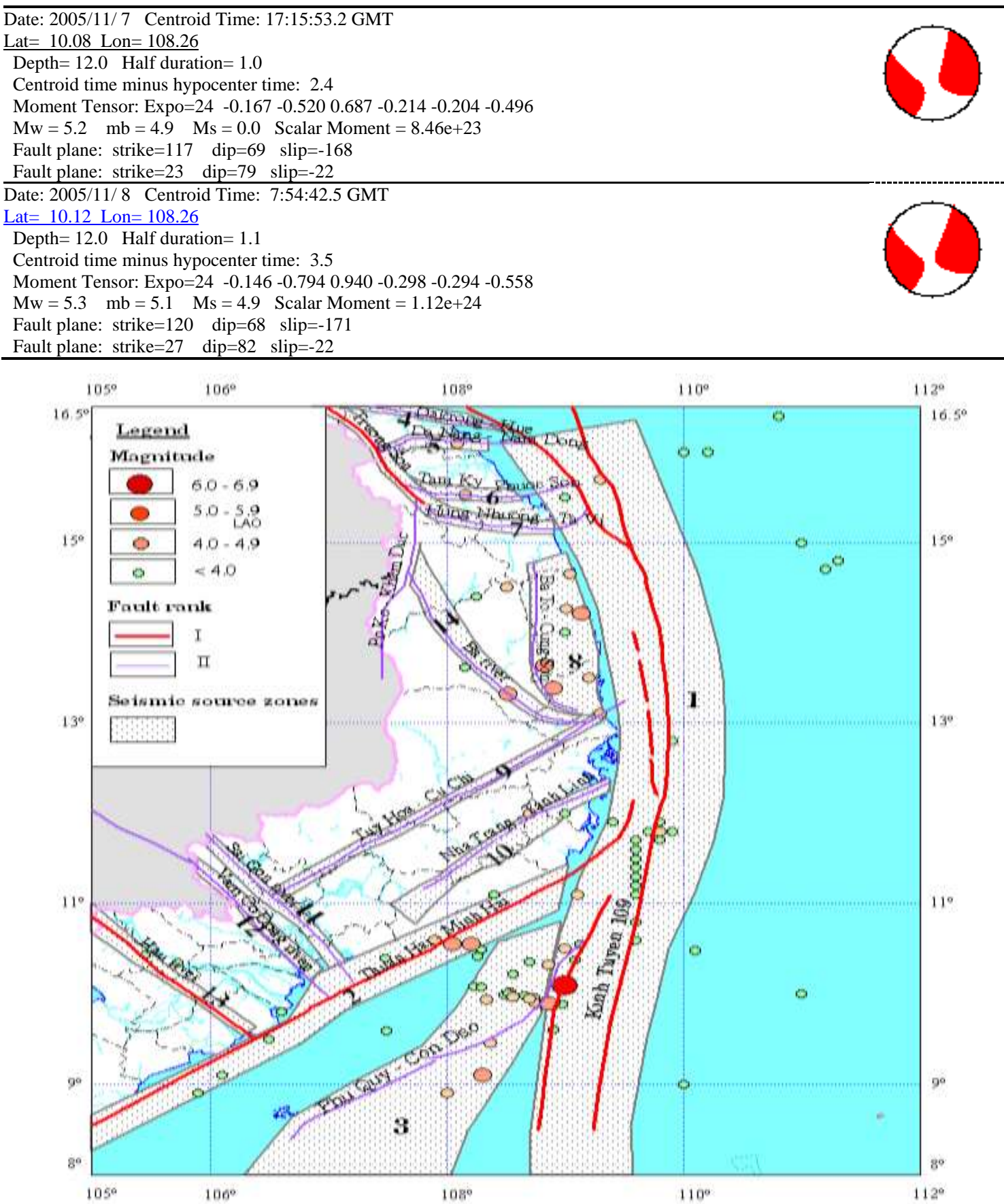

Fig.2. Seismotectonic map of the South Central Vietnam region. The earthquake data includes historical and instrumentally recorded events up to 2014. The faults names are given on the map (see Table 2 for detail), and the seismic source zones are numbered according to Table 3 
Vietnam Journal of Earth Sciences 36 (2014) 451-461

3. Active faults systems in the South Central Vietnam

In order to assess the seismic hazard for the South Central Vietnam region, the faults systems in the area with evidence of activities during present time are taking into consideration and are ranked according to their role as boundaries of tectonic units. By the rule, the faults of I rank are those which bound the tectonic plates, sub-plates or terrains during Ceinozoi. The faults of II rank are the secondary-born of the I rank ones, playing the role of boundary of the tectonic-geodynamic geoblocks or sub-geoblocks. Accordingly, the faults of III rank are the secondary-born of the II rank ones, playing the role of boundary of the tectonic-geodynamic sub-geoblocks and usually be limited inside the tectonic - geodynamic zones or sub-zones. The faults systems of I, II and III rank with focal depth exceeding $15-20 \mathrm{~km}$ can generate earthquakes.

The faults' activity has been assessed using remote sensing data and based on the geomorphologic evidence collected during the field trips, including mineral water or hot spring outcrops, surface rupture and land sliding, the release of $\mathrm{Rn}, \mathrm{Hg}$, Metan and Carbonic gazes and geothermal anomalies. Higher priority is given to the earthquakes data observed along the faults in present time or displacement amplitudes obtained from the high accuracy geodetic calculations. In other cases, when Quaternary sediment is crossed by a fault, the fault's age can be determined using the optically stimulated luminescence method.

The active faults systems in the South Central Vietnam have been studied by many authors (Department of Science and Technology of the Ho Chi Minh City, People Committee of Ho Chi Minh city, 2008; Institute of Energy, EVN, Ministry of Industry and Trade, 2003; N. H. Phuong et al., 2014; N. D. Xuyen et al., 2004). The research results show that the South Central Vietnam is characterized by 4 active faults systems distributed in NE-SW, NW-SE, latitudinal and meridional directions. Some main parameters of the active faults in the South Central Vietnam are listed in Table 2 .

For the seismic hazard assessment of the South Central Vietnam, several active faults systems in the South Vietnam were taken into consideration. A map of the main seismically active faults systems in the South Central Vietnam and South Vietnam used in this study is illustrated in Fig. 2.

Table 2. Main characteristics of the active faults systems in the South Central Vietnam region (Department of Science and Technology of the Ho Chi Minh City, People Committee of Ho Chi Minh city, 2008; Institute of Energy, EVN, Ministry of Industry and Trade, 2003; N. H. Phuong et al., 2014; N. D. Xuyen et al., 2004)

\begin{tabular}{|c|c|c|c|c|c|c|c|c|}
\hline $\mathrm{N}^{0}$ & Fault zone & Rank & Direction & Length $(\mathrm{km})$ & Width (km) & Depth (km) & Dip & $\begin{array}{c}\text { Movement mechanism } \\
\text { in } \mathrm{N}_{2}-\mathrm{Q} \\
\end{array}$ \\
\hline 1 & $109^{0}$ meridian Fault & $\mathrm{I}$ & Meridional & $>430(1100)$ & 100 & $\begin{array}{l}\text { Lithospheri } \\
\text { c }\end{array}$ & $\begin{array}{l}\mathrm{ESE} / 80 \text { - } \\
90^{\circ}\end{array}$ & $\mathrm{RL}-\mathrm{N}$ \\
\hline 2 & Thuan Hai - Minh Hai & I & NE-SW & $>380(660)$ & 60 & Crustal & $\mathrm{SE} / 70^{0}-75^{0}$ & $\mathrm{LL}-\mathrm{N}$ \\
\hline 3 & Da Nang - Nam Dong & II & Latitudinal & 160 & - & Crustal & $\mathrm{SW} / 60^{\circ}-70^{\circ}$ & RV \\
\hline 4 & Tam Ky - Phuoc Son & II & Latitudinal & 150 & - & Crustal & $\mathrm{N} / 60^{\circ}-70^{\circ}$ & $\mathrm{RV} / \mathrm{RL}$ \\
\hline 5 & Hung Nhuong - Ta Vi & I & Latitudinal & 125 & 30 & Crustal & $\mathrm{N} / 70^{\circ}-80^{\circ}$ & $\mathrm{R}-\mathrm{RL}$ \\
\hline 6 & Poko - Kham Duc & II & Meridional & $>200$ & 40 & Crustal & $\mathrm{W} / 70^{\circ}-80^{\circ}$ & $N-R L$ \\
\hline 7 & Truong Son & I & NW-SE & 750 & - & 30 & $\mathrm{SE} / 60^{\circ}-80^{\circ}$ & $R L-N$ \\
\hline 8 & Ba To - Cung Son & II & Meridional & $>110$ & 30 & $35-40$ & $\mathrm{E} / 70-80^{\circ}$ & LL -N \\
\hline 9 & Ba river & II & NW-SE & $250(>500)$ & $30-100$ & $35-40$ & $\mathrm{NE} / 70-84^{0}$ & RL - N \\
\hline 10 & Buon Ho & II & NW - SE & 150 & - & Crustal & $\mathrm{SW} / 80-85^{\circ}$ & RL - N \\
\hline 11 & Tuy Hoa - Cu Chi & II & NE - SW & 370 & 30 & Crustal & $\mathrm{NW} / 70-80^{\circ}$ & $\mathrm{LL}-\mathrm{N}$ \\
\hline 12 & Nha Trang - Tanh Linh & III & NE - SW & 285 & $20-40$ & 20 & $\mathrm{SE} / 70-80^{\circ}$ & LL - N \\
\hline
\end{tabular}

Note: Column (5): in parenthesis - maximum possible fault length based on geophysical data; $\mathrm{N}_{2}$ - Q - Pliocene - Quaternary, LL Left Lateral strike slip, RL- Right lateral, N - Normal, RV- Reverse, ( $>$ ) exceed, $(<)$ less than. 
Nguyen Hong Phuong et al./Vietnam Journal of Earth Sciences 36 (2014)

\section{Probabilistic seismic hazard assessment for the South Central Vietnam}

\subsection{Theoretical background}

An analytical method to determine seismic risk has been developed by Cornell (1968), which assesses the probability $P_{a}$ that in a time period of $T$ years the maximum intensity of ground motion at a site due to earthquakes from potential seismic sources will exceed $Y$ units. Here, the shaking intensity can be expressed in such parameters as acceleration $A$, velocity $V$ or displacement $D$. In addition, the results from a grid of different sites in a region can be used to construct a seismic risk map, which shows contours of ground motion intensity for various time periods.

Cornell's method was extended by McGuire (Cornell, 1968; McGuire, 1976) to calculate seismic risk using to the total probability theorem:

$$
P[A]=\int_{r} \int_{M} P[A \mid M, r] f_{M}(m) f_{R}(r) d M d r
$$

where $P$ indicates probability, $A$ is the event whose probability is sought, and $M$ and $r$ are continuous, independent random variables which influence $A$. In our case, $A$ represents the event that a specific value of ground motion intensity is exceeded at the site of interest during an earthquake, variables $M$ and $r$ represent earthquake size (magnitude) and distance from the site of interest. The integration on magnitude can be performed analytically, and the density function on distance $f_{R}(r)$ is given by the spatial relationship between the source and site.

\subsection{Seismic source zones}

Earthquakes in the coastal zone of South Central Vietnam are of two origins: tectonic and volcanic. As discussed by many authors, virtually all earthquakes of magnitude exceeding 4.5 in Vietnam have occurred along narrow fracture zones or faults, which have a prolonged development history and have been active during Recent as well as Present times (Department of Science and Technology of the Ho Chi Minh City, People Committee of Ho Chi Minh city, 2008; Institute of Energy, EVN, Ministry of Industry and
Trade, 2003; N. H. Phuong, 1999; N. H. Phuong et al., 2014; N. D. Xuyen et al., 2004). Many of these faults play the role of major boundaries of the principal structural elements in the region.

One of the first and important stage of an earthquake hazard assessment is the delineation of the seismic sources. The seismic source zones are defined on the basis of the studied rules of earthquake manifestation and their relationship with the geologic structure and the tectonic movement evidence in the study area. As a rule, a seismic source zone is defined along seismically active faults by summing all the possible rupture zones caused by maximum earthquakes, which might occur within given zone. In another words, this is the projection of tectonic fault plans counting from the lowest active layer to the Earth's surface. However, while delineating a seismic source zone boundary, this principle is rather flexible and sometimes extended, depending on certain observed earthquake epicenter distribution, a set of faults or related volcanic arcs, particularly in cases of scattered earthquake data. The acceptable boundary for a seismic source zone has to maintain all seismotectonic characteristics of the zone as a whole, namely the azimuthal location, direction of main geologic structures and cluster of earthquake epicenters.

To assess the seismic hazard for the South Central Vietnam region, 14 seismic source zones were delineated including 1 inland and 3 off-shore zones (See Table 3). Note that among the source zones used, three of them are located in the South Vietnam region, but their shaking effect to the South Central region have to be considered. Figure 2 shows a map of seismic source zones to be used in this study.

\subsection{Estimation of seismic hazard parameters for the seismic source zones}

In order to calculate and map the seismic hazard of the study region, the following earthquake hazard parameters, characterizing level of seismicity, were estimated for each seismic source zone:

- Expected maximum magnitude $M_{\max }$;

- Constants $a, b$ in the Gutenberg-Richter magnitude-frequency relation and their deductive values $\lambda, \beta$; 
Vietnam Journal of Earth Sciences 36 (2014) 451-461

- Mean return period $T(M)$ of the strong earthquakes with magnitude $M$.

Data treatment plays important role in a seismic hazard assessment procedure, particularly in case of probabilistic application, as one of the basic requirement of the earthquake data to be used that they have to be statistically independent with each other. For this reason, all earthquake data taken from the catalog was grouped by the seismic source zones into subcatalogs. Then for each source zone a statistical procedures were applied to remove all forshocks and aftershocks from the subcatalog prior to the computation.

The principle of aftershocks removal is wellknown and can be expressed simply as follows. Let $t$ be an origin time of earthquake occurrence, $h$ is a focal depth, $M$ is magnitude, $i$ and $j$ be order numbers of these earquakes in a catalog, and $\mathrm{j}>\mathrm{i}$. The second event can be considered as the aftershock of the first one if the following conditions are satisfied: the epicentral distance between the twoeventsislessthan a given value $\mathrm{R}\left(\mathrm{M}_{\mathrm{i}}\right), \mathrm{h}_{\mathrm{j}} \mathrm{h}_{\mathrm{i}} \leq \mathrm{H}(\mathrm{M})$; and $\mathrm{M}_{\mathrm{j}} \leq \mathrm{M}_{\mathrm{i}}$, where $\mathrm{T}(\mathrm{M})$, $\mathrm{R}(\mathrm{M})$ and $\mathrm{H}(\mathrm{M})$ are empirical functions (KeilisBorok et al., 1980). The algorithm of foreshock removal is similar.

The least square and the maximum likelihood methods were used for estimating the earthquake hazard parameters. Detail description of the estimation methods can be found in N. H. Phuong (1993, 1999). Then, the well-known Cornell's method and McGuire's computer program, which are based on assumptions of Poisson distribution of earthquake occurrence and double-truncated exponential distribution of magnitudes were used to assess the seismic hazard for the study area (Cornel, 1968; McGuire, 1976).

Although the statistical procedure was preferable to be used for estimating of the seismic hazard parametersfor each source zone, in such cases when the number of earthquakes within a source zone is not enough for a statistical analysis, a rule called „tectonic similarity“ was applied. The rule can be stated as follows: given for two source zones with similar tectonic condition, if for some reasons the seismic hazard parameters can only be estimated for one of them, the similar parameters can be asigned to the other one (N. D. Xuyen et al., 2004). The, tectonic similarity“ rule was applied for estimating seismic hazard parameters for the Tuy Hoa - Cu Chi and Vam Co Dong river source zones.

Table 3 lists the seismic hazard parameter estimated for the seismic source zones in the study area. The explanation for parameters listed in this table are given as follows : $\lambda_{0}$ - annual exceedance rate corresponding to $M_{0} ; N$ - number of earthquakes within each source zone; $M_{\text {max.obs. }}$ observed maximum magnitude; $M_{\text {max } \_M L}$ maximum earthquake value estimated by the maximum likelihood method (N. H. Phuong, 2009, 2014); $M_{0}$ - lower threshold of magnitude value used; $B_{M L^{-}}$the b value (in the Gutenberg - Richter relationship) derived from the maximum likelihood results; $H$ - thickness of the active layer of each source zone.

Table 3. Seismic hazard parameter estimated for the seismic source zones in the South Central Vietnam region

\begin{tabular}{|c|c|c|c|c|c|c|c|c|}
\hline TT & Source zone & $\lambda\left(\mathrm{M}_{0}\right)$ & $\mathrm{N}$ & $\mathrm{M}_{\max }$ obs. & $\mathrm{M}_{\max } \mathrm{ML}$ & $\mathrm{M}_{0}$ & $\mathrm{~B}_{\mathrm{ML}}$ & $\mathrm{H}(\mathrm{km})$ \\
\hline 1 & $109^{\circ}$ Meridian Fault & 0.437 & 21 & 6.1 & $6.6 \pm 0.28$ & 4.0 & 0.28 & 12 \\
\hline 2 & Thuan Hai - Minh Hai & 0.434 & 5 & 5.1 & $5.6 \pm 0.30$ & 4.0 & 0.32 & 12 \\
\hline 3 & Cuu long - Con Sơn & 0.181 & 2 & 5.1 & $5.7 \pm 0.38$ & 4.0 & 0.51 & 10 \\
\hline 4 & Dakrong - Hue & 0.016 & 2 & 4.8 & 5.3 & 4.0 & 1.0 & 12 \\
\hline 5 & Da Nang & 0.02 & 1 & 4.8 & 5.3 & 4.0 & 1.0 & 12 \\
\hline 6 & Tam Ky - Phuoc Son & 0.02 & 1 & 4.7 & 5.2 & 4.0 & 1.0 & 12 \\
\hline 7 & Hung Nhuong - Ta Vi & 0.03 & 2 & - & $6.2 \pm 0.54$ & 4.0 & 0.63 & 12 \\
\hline 8 & Ba To - Cung Sơn & 0.034 & 9 & 5.3 & $5.8 \pm 0.54$ & 4.0 & 0.14 & 12 \\
\hline 9 & Tuy Hoa - Cu Chi & 0.02 & 1 & 4.8 & 5.3 & 4.0 & 1.0 & 10 \\
\hline 10 & Nha Trang Tanh Linh & 0.4 & 2 & 4 & $4.5 \pm 0.47$ & 4.0 & 0.59 & 10 \\
\hline 11 & Saigon river & 0.02 & - & - & $4.5 \pm 1.56$ & 4.0 & 1.16 & 10 \\
\hline 12 & Vam CoDong river & 0.02 & 3 & 4.0 & $4.5 \pm 1.56$ & 4.0 & 1.16 & 10 \\
\hline 13 & Hau river & 0.02 & 2 & 4.4 & $4.9 \pm 0.35$ & 4.0 & 0.36 & 12 \\
\hline 14 & Ba river & 0.01 & 2 & 5.0 & 5.1 & 4.0 & 0.84 & 12 \\
\hline
\end{tabular}


Nguyen Hong Phuong et al./Vietnam Journal of Earth Sciences 36 (2014)

\subsection{Attenuation equation}

The establishment of an attenuation equation to be applied for a study region is important and usually considered as a separate stage in the whole seismic hazard assessment procedure (International Atomic Energy Agency, 2003). In Vietnam, due to the lack of strong ground motion data, for a long time no local attenuation equations have been developed. Although since 2011, two attenuation equations have been published by Vietnamese scientists, none of them are used untill now as the reliability of these equations has been in the process of verification (N. L. Minh et al., 2012; T. V. Hung and Kiyomiya, 2012).

In this study, an attenuation equation developped by Toro, Abrahamson and Schneider (1997) was used for the compilation of probabilistic seismic hazard maps of the South Central Vietnam region. This equation was developped for the Central and Eastern North America, a seismically stable region as compared with the Western America. As the seismicity condition of the Eastern US and the South Central Vietnam is comparable, it is preferable to use the Toro et al. (1997) for the seismichazard assessment of the South Central Vietnam region.

The functional form of the atenuation equation proposed by Toro, Abrahamson and Schneider (1997) is the following (Toro et al.,1997):

$$
\begin{gathered}
\ln Y=C_{1}+C_{2}(M-6)+C_{3}(M-6)^{2}-C_{4} \ln R_{M}-\left(C_{5}-\right. \\
\left.C_{4}\right) \max \left[\ln \left(\frac{R_{M}}{100}\right), 0\right]-C_{6} R_{M}+\varepsilon_{e}+\varepsilon_{a} \\
R_{M}=\sqrt{R_{j b}^{2}+C_{7}^{2}}
\end{gathered}
$$

where $\mathrm{Y}$ is spectral acceleration or peak ground acceleration (in unit of $\mathrm{g}$ ), $\mathrm{c}_{1}$ through $\mathrm{c}_{7}$ are constants determined by the modeling, $\mathrm{M}$ is the moment magnitude, $R_{M}$ is hypocentral distance and $R_{j b}$ is the closest horizontal distance (or Joyner and Boore distance) to the earthquake rupture $(\mathrm{km})$.

\subsection{Probabilistic seismic hazard maps of South Central Vietnam}

The CRISIS2007 program developed by Ordaz et al (year?) was applied to compute seismic hazard for the South Central Vietnam region, using the following input data:

(1) A scheme of seismic source zones of South Central Vietnam (Fig. 2).
(2) Seismic hazard parameters of the seismic source zones (Table 3 ).

The peak ground acceleration (in units of $\% g$ ) was calculated in each point of a $0,1^{\circ} \times 0,1^{\circ}$ grid covering the study area. Obtained PGA values were used for compilation of a set of seismic hazard maps depicting peak horizontal ground acceleration with $10 \%, 5 \%, 2 \%$ and $0.5 \%$ probabilities of exceedance in 50 years, corresponding to return times of about 500, 1000, 2500 and 10000 years, respectively. These maps are illustrated in Fig. 3a, b, c and d, showing spatial distribution of Peak Ground Acceleration (PGA) in unit of $\% \mathrm{~g}$. From the seismic hazard maps in Fig. 3, some preliminary conclusion can be made as follows:

(1) It can be seen that the spatial distribution of PGA values clearly reflects seismic sources in the territory as well as in the continental shelf of the South Central Vietnam region.

(2) The highest values of PGA are observed in the continental shelf of the South Central Vietnam, in the $109^{\circ}$ meridian fault source zone. Here, the maximum PGA values are $0.12,0.15,0.2$ and 0.28 $\mathrm{g}$ corresponding to the return times of about 500, 1000,2500 and 10000 years, respectively. It should be noted that for the return period of 10000 years, maximum shaking in this source zone corresponds with the intensity of IX (I=IX by MSK-64 scale). In addition, two seismic source zones that can produce strong ground shaking offshore South Central coast are Cuu Long - Con Son and Thuan Hai - Minh Hai. For the time period of about 1000 years, the highest shaking intensity within these source zones reaches the value of VIII (I=VIII by MSK-64 scale).

(3) In the territory of South Central Vietnam, the strongest shaking are observed in the Quang Nam and Quang Ngai provinces, in the Hung Nhuong - Ta Vi seismic source zone. For the return times of about 500, 1000, 2500 and 10000 years, the highest PGA values in this zone are 0.1 , $0.12,0.14$ và $0.17 \mathrm{~g}$, respectively. It should be noted that for the return time of about 10000 years, the shaking intensity within this source zone reach the value of VIII (I = VIII by MSK-64 scale). The strong ground motions are also observed in some seismic source zones areas as Tuy Hoa - $\mathrm{Cu}$ Chi, Hau river and Nha Trang Tanh Linh. 
Vietnam Journal of Earth Sciences 36 (2014) 451-461
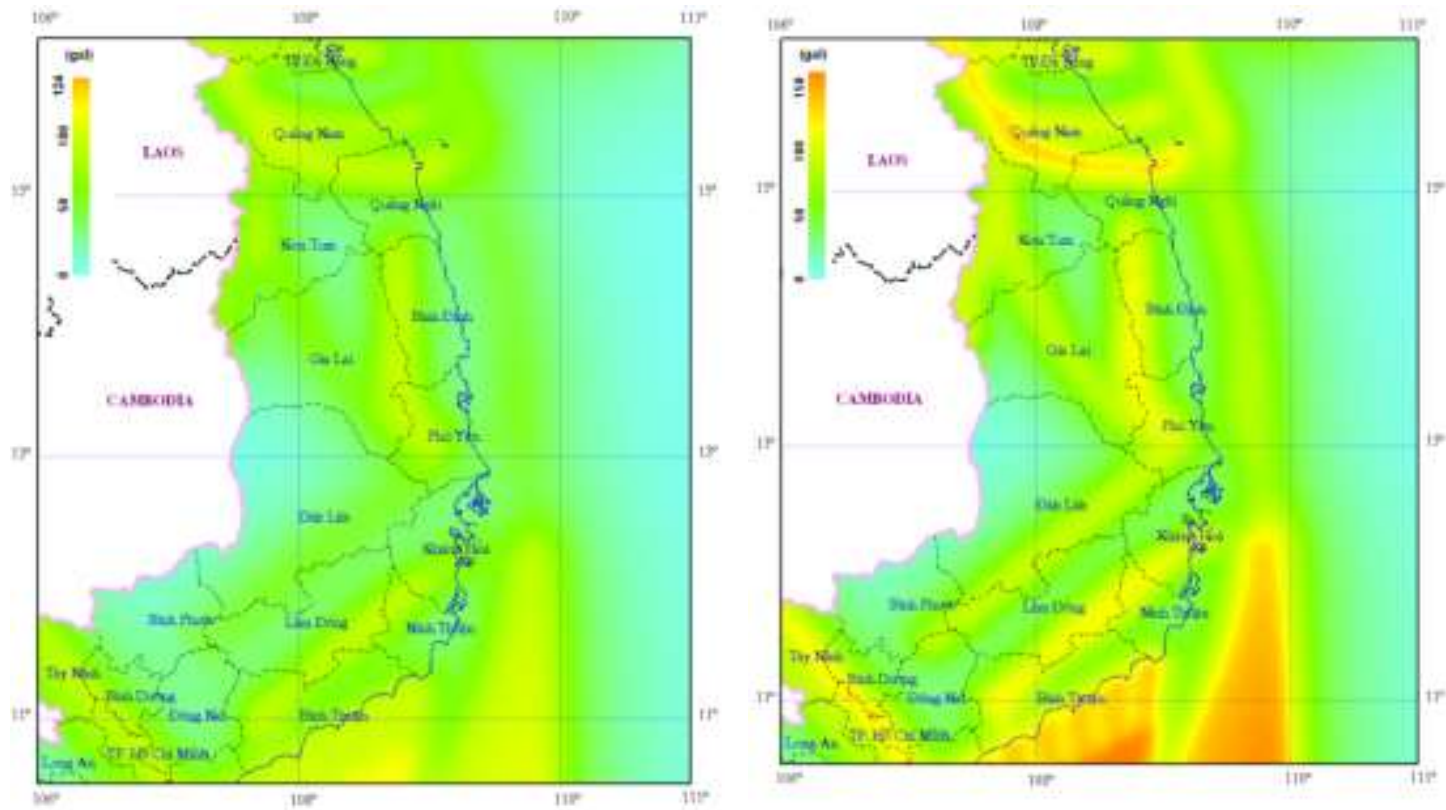

$\mathrm{a}$
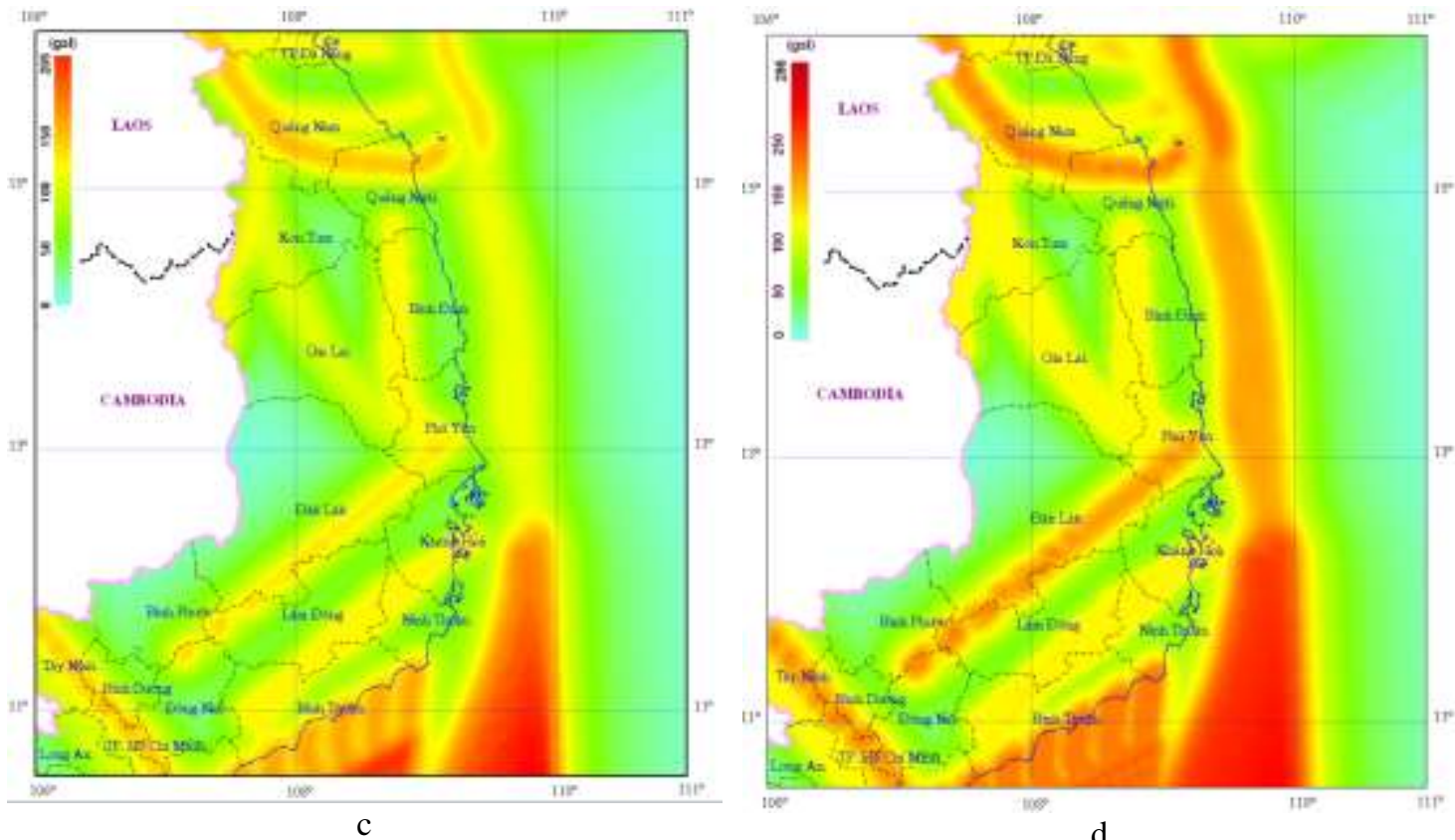

Fig. 3. Probabilistic Seismic Hazard Map of South Central Vietnam in terms of Peak Ground Acceleration (\% g), with $10 \%, 5 \%, 2 \%$ and $0.5 \%$ probabilities of exceedance in 50 years, respectively

\section{Discussion}

One of the advantages of the PGA maps presented in this study is that they were compiled on the basis of a most comprehensive source zones model ever created for the South Central Vietnam up to now. The model inherits the results of the previous studies by N. D. Xuyen et al., (2004),N. H. Phuong (2004) and N. H. Phuong et al., (2010). For assessing seimic impact from Southern Laos to Vietnam, the Hung Nhuong - Ta Vi source zone was included in the model.

In addition, the use of earthquakes data updated untill 2014 and a new version of computational 
Nguyen Hong Phuong et al./Vietnam Journal of Earth Sciences 36 (2014)

tool, namely the CRISIS 2007 software enhances the effectiveness and reliability of the calculation results.

By the delineation of seismic source zones and the attenuation equation used and time periods considered, the PGA maps presented in this study are mostly comparable with those of N. D. Xuyen et al., 2004. Table 4 shows comparison of PGA values obtained from the two studies at some places. As can be seen from the Table, the difference between these values if negligible.

Table 4. Comparison of PGA values calculated by N. D. Xuyen et al., (2004) and N. H. Phuong et al., (2014), the values are presented in $\mathrm{g}$.

\begin{tabular}{|c|c|c|c|c|c|}
\hline \multirow{3}{*}{$\mathrm{N}$} & & & \multicolumn{3}{|c|}{ Time period (in years) } \\
\hline & & & 475 & & 975 \\
\hline & & $\mathrm{X}$ & $\mathrm{P}$ & $\mathrm{X}$ & $\mathrm{P}$ \\
\hline 1 & $109^{0}$ Meridian Fault & 0.12 & 0.12 & 0.12 & 0.15 \\
\hline 2 & Cuu long - Con Son & 0.12 & 0.12 & 0.17 & 0.15 \\
\hline 3 & Thuan Hai - Minh Hai & 0.12 & 0.10 & 0.17 & 0.12 \\
\hline 4 & Hung Nhuong - Ta Vi & 0.12 & 0.10 & 0.17 & 0.12 \\
\hline 5 & Tuy Hoa - Cu Chi & 0.0 & 0.07 & 0.12 & 0.09 \\
\hline 6 & Nha Trang - Tánh Linh & 0.0 & 0.09 & 0.12 & 0.11 \\
\hline
\end{tabular}

\section{Conclusion}

In this paper, a probabilistic method was applied to assess seismic hazard for the South Central Vietnam. Using the most recent seismological and geological data, a seismotectonic model was developped and 14 seismic sources zones were delineated for use. In results, a set of new probabilistic seismic hazard maps of the South Central Vietnam was compiled depicting peak horizontal ground acceleration with $10 \%, 5 \%, 2 \%$ and $0.5 \%$ probabilities of exceedance in 50 years, corresponding to return times of about 500, 1000, 2500 and 10000 years, respectively.

The highest values of PGA are observed in the continental shelf of the South Central Vietnam, in the $109^{\circ}$ meridian source zone, where the maximum PGA values are $0.12,0.15,0.2$ and 0.28 $\mathrm{g}$ corresponding to the return times of about 500 , 1000, 2500 and 10000 years, respectively. In addition, two seismic source zones that can produce strong ground shaking off-shore South Central coast are Cuu Long - Con Son and Thuan Hai - Minh Hai. For the time period of about 1000 years, the highest shaking intensity within these source zones reaches the value of VIII (I=VIII by MSK-64 scale). In the territory of South Central Vietnam, the strongest shaking are observed in the Quang Nam and Quang Ngai provinces, in the Hung Nhuong - Ta Vi seismic source zone. For the return times of about 500, 1000, 2500 and 10000 years, the highest PGA values in this zone are 0.1 , $0.12,0.14$ và $0.17 \mathrm{~g}$, respectively. Strong ground shakings are also observed in some other seismic source zones as Tuy Hoa - $\mathrm{Cu} \mathrm{Chi}$, Hau river and Nha Trang - Tanh Linh.

The newly update PGA maps presented in this study can be considered as a revised version of the existing 2010 ones. The derived probabilistic seismic hazard present both short-term and longterm forecasts of seismic hazard and can be used as the basis for antiseismic design as well as in other applications such as loss estimation and emergency planning for the South Central Vietnam region.

\section{References}

Cornell, C. A., 1968: Engineering Seismic Risk Analysis, Bull. Seim. Soc. Am.,58, pp. 1583 - 1606.

Department of Science and Technology of the Ho Chi Minh City, People Committee of Ho Chi Minh city, 2008: 1 Report of the $1^{\text {st }}$ Stage of implementation of the Project "Seismic Microzoning of the Ho Chi Minh city", Ho Chi Minh City (in Vietnamese).

International Atomic Energy Agency, 2003: Site Evaluation for Nuclear Installations. IAEA Safety Standards Series No. NS-R-3, IAEA, Vienna.

Institute of Energy, EVN, Ministry of Industry and Trade, 2003: Feasibility report of investment and construction of NPP in Ninh Thuan, Vol. 3, Appendix, Book 2/2 (in Vietnamese).

Keilis-Borok, V.I., Knopoff, L., Rotwain, I.M., 1980: Burst of aftershocks, long-term precursors of strong earthquakes, Nature, Vol. 283, 259-263.

L. T. Son et al., 2006: Investigation of the Phan Thiet - Vung Tau earthquake of November 8, 2005. Field trip report, Dept. of earthquake observation, Institute of Geophysics, Hanoi.

McGuire, R.K., 1976: FORTRAN computer program for seismic risk analysis, U.S. Geol. Survey Open - File Rept. 76-67, 89. 
Vietnam Journal of Earth Sciences 36 (2014) 451-461

N. K. Mao, 1974: Seismic zoning of South Vietnam. Bulletins of Universities.

N. L. Minh et al, 2012: The first peak ground motion attenuation relationships for North of Vietnam, Journal of Asian Earth Sciences, doi: 10.1016/j.jseaes.2011.09.012.

N. H. Phuong, 1991: Probabilistic Assessment of Earthquake Hazard in Vietnam based on Seismotectonic Regionalization, Tectonophysics, 198, 81-93, Elsevier Publisher.

N. H. Phuong, 1993: Probabilistic earthquake hazard assessment for the territory of Vietnam, Ph.D. thesis, Smith Institute of Physics of the Earth, Academy of Sciences of Russian Federation, Moscow (In Russian).

N. H. Phuong, 1999: Investigation of the Relation between Seismicity and Elements of Geodynamics along the Southeastern Coast of Vietnam. Proceedings of the International Workshop on Tectonics, Geodynamics and Natural Hazards in West Pacific-Asia. Journal of Geology, Series B, No13-14/99, pp.179-193.

N. H. Phuong, 2004: Probabilistic seismic hazard maps of Vietnam and the East Vietnam Sea. Vietnam Journal of Earth Sciences, 26(2), 97-111 (in Vietnamese).

N. H. Phuong, 2010: Chapter V. Seismic hazard and seismic risk in the coastal zones and islands of Vietnam. In: B. C. Que (editor). "Earthquakes and tsunamis hazards in the coastal zones of Vietnam", Natural Science and Technology Publ. House, Hanoi, 312 pp. (in Vietnamese).

N. H. Phuong, B. C. Que, N. D. Xuyen, 2012: Investigation of tsunami sources, capable of affecting the Vietnamese coast. Natural Hazards, 64(1) pp 311-327. DOI: 10.1007/s11069012-0240-3, October 2012.

N. H. Phuong et al., 2014: Assessment of earthquake and tsunami hazards in the Ninh Thuan province for site approval of the NPPs. Final report of the National
Scientific Research Project N ${ }^{\mathrm{o}}$ 02-2012/HĐ-ĐTĐL, Hanoi.

N. D. Xuyen et al., 1981: Additional earthquakes data from questionnaires. Field trip report on earthquakes during 1979 - 1981. Department of Physics of the Earth - Vietnam Institute of Sciences, Hanoi (in Vietnamese).

N. D. Xuyen et al., 2004: Final report of the National scientific research project on "Study of earthquake prediction and ground motion in Vietnam. Final report of the National scientific research project on "Study of earthquake prediction and ground motion in Vietnam", Institute of Geophysics, Hanoi, (in Vietnamese).

Ordaz M., Aguilar A., Arboleda J. CRISISS99. University of Mexico (UNAM).

Petersen, M. D. Dewey, J., Hartzell, S., Mueller, C., Harmsen, S., Frankel, A.D., Rukstales K., 2004: Probabilistic seismic hazard analysis for Sumatra, Indonesia and across the Southern Malaysian Peninsula. Tectonophysics,390 (2004) 141-158.

T. V. Hung and Kiyomiya, O., 2012: Ground motion attenuation relationship for shallow strike-slip earthquakes in northern Vietnam based on strong motion records from Japan, Vietnam and adjacent regions, Structural Eng./Earthquake Eng., JSCE, 29: 23-39.

P. V. Thuc, 2008: Relationship of earthquakes and volcanoes activities in the South Central Coast, Journal of Marine Science and Technology, No 2(8), Hanoi.

Toro, G. R., Abrahamson, N. A. and Schneider, J. F., 1997: Engineering Model of Strong Ground Motions from Earthquakes in the Central and Eastern United States, Seismological Research Letters, January/February.

V. M. Giang, 2000: Earthquakes and other natural disasters through the historical data. Institute report, Institute of Geophysics. 